\title{
Review on Finite Element Material Modelling Of Brain Tissue for Surgical Simulation
}

\author{
Faris Tarlochan, Siva Mahesh Tangutooru \\ ${ }^{a}$ Department of Mechanical and Industrial Engineering, Qatar University, Qatar
}

\begin{abstract}
Surgical simulation is a growing field of interest as it serves as a good training for the medical practitioners as well as planning and preparing for surgery. For a reliable and a good outcome from the simulation, the challenge is to model the material properties of tissues as accurate as possible. For a real time surgical simulation the numerical model has to be simple and computationally inexpensive. One of the preferred numerical models is the finite element model. Hence, the objective of this paper is to review finite element modelling of the brain tissue. The human brain tissue is an interesting organ to be studied because of their use in understanding trauma related injuries and tissue injury mechanism during brain surgery.
\end{abstract}

\section{Introduction}

Interactive and real time surgical simulation is a very important tool in today's health care industry [1 - 5]. Latest technology has reduced to less invasive surgeries by the surgeons. This is accomplished by smaller cuts during surgery. This results in loss of direct contact and tactile information to the surgeons. As a result, surgeons need to adapt themselves to improve their hand-eye coordination. Here simulation tools such as finite element models can to some extend accurately predict tissue injuries. This is also useful for surgeons to practice and plan their surgeries [6-8].

The motivation for this review paper is related to an ongoing research onto addressing the high incidence of blindness in eastern Arabia. Glaucoma is the major ophthalmological challenge for the eastern Arabian population. Glaucoma destroys retinal ganglion cells, the neurons which connect the eye to the visual brain. Without these cells visual signals cannot reach those parts of the central nervous system that give rise to perceptions. Since human ganglion cells do not grown anew and once lost are gone forever, the only practical means of restoring vision to those blinded through glaucoma is a neuroprostheses that interfaces visual neurons of the brain to stimulating electrodes driven by an image capture system and electronic circuitry. This involves navigating the electrodes and penetrating the brain tissue to reach the target side. Hence one of the objectives is to study the level of tissue injury by means of the penetrating electrode. This will help in planning the trajectory for the invasion. Hence a finite element model that best represents the brain tissue will be needed.
This paper will share all the developed brain tissue material models for finite element analysis along with their limitations.

\section{Material Models}

The main key in developing brain tissue finite element material model is the level of accuracy needed. There is a paradox here where the surgical simulation of tissues has to be simple to be used for a broad range of medical conditions but with sufficient complexity to realistically describe the accurate physical response due to variety of applied loading conditions. The review of various material models will help in identifying a solution for this paradox.

\section{$\underline{\text { Linear Elastic Models }}$}

Linear elastic models are commonly used in most finite element analysis as it is the easiest to be implemented in terms of computational time and setting the model up. Several researchers have developed linear elastic model for measuring brain deformation [9 - 12]. From [12], it was found that for a strain rate of $0.01 \mathrm{~s}-1$ (quasi static testing) of actual brain tissue, the tissue can be approximated with a linear elastic model provided the strain does not exit $10 \%$. Higher strain values will significantly differ between the linear model and the observe experimentation data. Even though the brain tissue can be approximated with linear elastic model, however from a clinical point of view this is not really good since most surgical procedures involve deformations of more than $10 \%$ [12].

Hyperelastic Models 
Hyperelastic material model is used to describe the nonlinear stress-strain behaviour of complex materials such as tissues. The model assumes that the material behaviour can be described by means of a strain energy density function, from which the stress-strain relationships can be derived. Hyperelastic materials can be considered to be isotropic, incompressible and strain rate independent. Due to the large deformations seen on tissues during surgeries, these models are used extensively for all kinds of tissues such as brain [13, 18], liver tissue [14], skin [15], soft tissues [16] and for general laparoscopic simulation [17]. The relevant equations of the strain energy function can be explained as follows [18]:

Hyperfoam function:

$$
\begin{gathered}
U=\sum_{i=1}^{N}\left[\frac{2 \mu_{i}}{\alpha_{i}^{2}}\left(\varphi_{1}^{\alpha_{i}}+\varphi_{2}^{\alpha_{i}}+\varphi_{3}^{\alpha_{i}}-3\right)\right. \\
\left.+\frac{1}{\beta_{i}}\left(J^{-\alpha_{i} \beta_{i}}-1\right)\right]
\end{gathered}
$$

Where $\varphi \mathrm{i}$ are the principal stretches: $\mathrm{J}$ is the determinant of the deformation gradient tensor; $\mathrm{N}$ is the number of terms; and $\mu, \alpha, \beta$ are material parameters.

\section{Ogden Strain Energy Potential:}

$$
\begin{gathered}
U=\sum_{i=1}^{N} \frac{2 \mu_{i}}{\alpha_{i}^{2}}\left(\bar{\varphi}_{1}^{\alpha_{i}}+\bar{\varphi}_{2}^{\alpha_{i}}+\bar{\varphi}_{3}^{\alpha_{i}}-3\right) \\
+\sum_{i=1}^{N} \frac{1}{D_{i}}(J-1)^{2 i}
\end{gathered}
$$

Where $\varphi \mathrm{i}$ are the deviatoric principal stretches, D are material parameters.

Polynomial Strain Energy Potential:

$$
\begin{array}{r}
U=\sum_{i+j=1}^{N} C_{i j}\left(I_{1}-3\right)^{i}\left(I_{2}-3\right)^{j} \\
+\sum_{i=1}^{N} \frac{1}{D_{i}}(J-1)^{2 i}
\end{array}
$$

Where $\mathrm{Cij}$ are material parameters and $I_{1}$ and $I_{2}$ are the first and second deviatoric strain invariants. From the study conducted by Moran et al [18], it was found that the Hyperfoam, Ogden and polynomial functions have relatively good fit to the experimental data. The coefficient of determination for the Hyperfoam, Ogden and Polynomial were $0.97,0.92$ and 0.80 respectively. In order to achieve a good fit, a value of $\mathrm{N}=2$ had to be used to avoid strain softening. For each of the above functions the Poisson's ratio were $0.38,0.42$ and 0.44 respectively. Hyperfoam model was the best amongst the three models for the compression test. In terms of shear test, the polynomial function did not fare as well. Tables 1-3 show the parameters for all the three models obtained from [18].

\section{Viscoelastic Models}

The coupling of elasticity and viscosity creates a viscoelastic material with specific mechanical responses and it needs specific experimental investigations and modelling approaches. Viscoelastic materials are materials where the stress and strain depends on time or, in the frequency domain, on frequency. Polymers are good example of viscoelastic materials. Several researchers have used linear viscoelastic models to model the brain tissue [19]. This model has also been used by other researchers to model other tissues such as liver [20 21] and joints [22]. Some have used this for surgical simulation purpose [23, 24].

For the brain tissue, it is not very accurately to represent them as linear viscoelastic. To some extend brain tissues are non-linear viscoelastic [12]. Several researchers have worked in this aspect to develop non-linear viscoelastic material model for finite element application [25, 26]. Even though the nonlinear viscoelastic model is a good representation of the brain tissue, it is difficult to estimate the parameter values for the model and can be computationally expensive [27].

Some researchers tried to improve the linear viscoelastic model by introducing quasi-linear viscoelastic viscoelasticity [12]. Here the tissue is assumed to have two material behaviour: a time dependent elastic response and a linear viscoelastic stress relaxation response. It was found that this model fits experimental behaviour accurately up to strains of $15 \%$, a much better improvement than the linear elastic models.

The finite element (FE) model for the brain has vast applications. For specific applications, it is important to specific the domain of the brain where a particular response is being computed. This requires discretization of the brain itself. The discretization depends on the nature of the surgery if it requires patient specific information. This leads to the development of a computational grid based on CT and MRI images. Due to computational time efficiency, low order elements are preferred such as linear hexahedron elements to discretize the computational grid. However, due to complexity that arrives due to the presence of tumors, mixed meshes having both hexahedral and linear tetrahedral elements are the most convenient [28]. Figure 1 depicts the patient specific discretization using finite elements. Variations of brain FE models exist with element densities varying from 9000 elements to 50000 elements [29]. Hence this indicating the element size depends on the accuracy 
details, the model of the brain itself and the type of response required.

Table 1: Parameters for Hyperfoam [18]

\begin{tabular}{|c|c|c|c|c|c|c|c|c|c|}
\hline $\begin{array}{c}\text { Brain } \\
\text { Tissue } \\
\text { Regio } \\
\text { n } \\
\end{array}$ & $\begin{array}{c}\mathrm{Mu} \\
1 \\
(\mathrm{~Pa})\end{array}$ & $\begin{array}{c}\text { Alpha } \\
1\end{array}$ & $\begin{array}{c}\text { Mu } 2 \\
(\mathrm{~Pa})\end{array}$ & $\begin{array}{c}\text { Alpha } \\
\mathbf{2}\end{array}$ & $\begin{array}{c}\beta_{1}, \\
\beta_{2}\end{array}$ & $\begin{array}{c}\mathbf{G} \\
(\mathbf{P a})\end{array}$ & $\begin{array}{c}R^{2} \\
\text { Comp } \\
\text { ressio } \\
n\end{array}$ & $\begin{array}{c}\mathbf{R}^{2} \\
\text { Ten } \\
\text { sion }\end{array}$ & $\begin{array}{c}\mathbf{R}^{2} \\
\text { She } \\
\text { ar }\end{array}$ \\
\hline $\begin{array}{l}\text { White } \\
\text { matter }\end{array}$ & $\begin{array}{c}67.1 \\
9\end{array}$ & 10.65 & $\begin{array}{c}981.6 \\
7\end{array}$ & -3.45 & $\begin{array}{c}9 . \\
15 \\
1 . \\
57\end{array}$ & $\begin{array}{c}104 \\
8\end{array}$ & 0.97 & 0.98 & 0.98 \\
\hline $\begin{array}{c}\text { Gray } \\
\text { matter }\end{array}$ & $\begin{array}{c}76.4 \\
6\end{array}$ & 10.96 & $\begin{array}{c}1267 . \\
70\end{array}$ & -3.20 & $\begin{array}{c}11 \\
.7 \\
0, \\
0 . \\
89\end{array}$ & $\begin{array}{c}134 \\
4\end{array}$ & 0.97 & 0.98 & 1.00 \\
\hline $\begin{array}{c}\text { Coron } \\
\text { a } \\
\text { radiata }\end{array}$ & $\begin{array}{c}75.5 \\
0\end{array}$ & 11.63 & $\begin{array}{c}1359 . \\
40\end{array}$ & -3.84 & $\begin{array}{c}12 \\
.0 \\
0, \\
0 . \\
72\end{array}$ & $\begin{array}{c}143 \\
4\end{array}$ & 0.97 & 0.98 & 1.00 \\
\hline
\end{tabular}

Table 2: Parameters for Ogden [18]

\begin{tabular}{|c|c|c|c|c|c|c|c|c|c|}
\hline $\begin{array}{c}\text { Brain } \\
\text { Tissue } \\
\text { Regio } \\
\text { n } \\
\end{array}$ & $\begin{array}{c}\text { Mu } \\
1 \\
\text { (Pa) }\end{array}$ & $\begin{array}{c}\text { Alpha } \\
1\end{array}$ & $\begin{array}{c}\text { Mu } 2 \\
(\mathrm{~Pa})\end{array}$ & $\begin{array}{c}\text { Alpha } \\
\mathbf{2}\end{array}$ & $\begin{array}{l}\mathbf{D}_{1}, \\
\mathbf{D}_{2}\end{array}$ & $\begin{array}{l}\text { G } \\
\text { (P } \\
\text { a) }\end{array}$ & $\begin{array}{c}\mathrm{R}^{2} \\
\text { Com } \\
\text { pressi } \\
\text { on }\end{array}$ & $\begin{array}{c}\mathbf{R}^{2} \\
\text { Ten } \\
\text { sion }\end{array}$ & $\begin{array}{c}\mathrm{R}^{2} \\
\text { She } \\
\text { ar }\end{array}$ \\
\hline $\begin{array}{l}\text { White } \\
\text { matter }\end{array}$ & $\begin{array}{c}71.3 \\
3\end{array}$ & 11.61 & $\begin{array}{c}826.3 \\
5\end{array}$ & -6.07 & $\begin{array}{c}3.13 \\
\text { E- } \\
04, \\
4.98 \\
\text { E-04 }\end{array}$ & $\begin{array}{c}89 \\
7\end{array}$ & $\begin{array}{l}0.99 \\
\end{array}$ & 0.98 & 0.99 \\
\hline $\begin{array}{c}\text { Gray } \\
\text { matter }\end{array}$ & $\begin{array}{c}116 . \\
43\end{array}$ & 7.49 & $\begin{array}{c}1058 . \\
9\end{array}$ & -6.75 & $\begin{array}{c}3.19 \\
\text { E- } \\
04, \\
3.89 \\
\text { E-04 }\end{array}$ & $\begin{array}{l}11 \\
75\end{array}$ & 0.98 & 0.96 & 0.99 \\
\hline $\begin{array}{l}\text { Coron } \\
\text { a } \\
\text { radiata }\end{array}$ & $\begin{array}{c}90.9 \\
4\end{array}$ & 6.97 & $\begin{array}{c}1150 . \\
6\end{array}$ & -7.42 & $\begin{array}{c}3.18 \\
\text { E- } \\
04, \\
2.62 \\
\text { E-04 } \\
\end{array}$ & $\begin{array}{l}12 \\
41\end{array}$ & 0.98 & 0.92 & 0.99 \\
\hline
\end{tabular}

Table 3: Parameters for polynomial function [18]

\begin{tabular}{|c|c|c|c|c|c|c|c|c|c|c|}
\hline $\begin{array}{c}\text { Brai } \\
\text { n } \\
\text { Tiss } \\
\text { ue } \\
\text { Regi } \\
\text { on } \\
\end{array}$ & $\begin{array}{l}\text { C10 } \\
\text { (Pa) }\end{array}$ & $\begin{array}{l}\mathrm{C} 01 \\
\text { (Pa) }\end{array}$ & $\mathbf{C 2 0}$ & C11 & $\mathrm{C02}$ & $\begin{array}{l}\mathbf{D}_{1} \\
\mathbf{D}_{2}\end{array}$ & $\begin{array}{l}\text { G } \\
\text { (P } \\
\text { a) }\end{array}$ & $\begin{array}{c}\mathrm{R}^{2} \\
\text { Co } \\
\mathrm{mp} .\end{array}$ & $\begin{array}{c}\mathbf{R}^{2} \\
\text { Ten } \\
\text { sion }\end{array}$ & $\begin{array}{c}\mathbf{R}^{2} \\
\text { Sh } \\
\text { ea } \\
\mathbf{r}\end{array}$ \\
\hline $\begin{array}{c}\text { Whit } \\
\mathrm{e} \\
\text { matt } \\
\text { er }\end{array}$ & $\begin{array}{c}- \\
145 \\
5\end{array}$ & 2186 & $\begin{array}{c}323 \\
5\end{array}$ & $\begin{array}{c}- \\
527 \\
6\end{array}$ & $\begin{array}{c}187 \\
5\end{array}$ & $\begin{array}{c}3.13 \\
\text { E- } \\
04, \\
0.00 \\
\end{array}$ & $\begin{array}{l}14 \\
62\end{array}$ & 1.00 & 0.95 & $\begin{array}{c}0 . \\
98\end{array}$ \\
\hline $\begin{array}{c}\text { Gray } \\
\text { matt } \\
\text { er }\end{array}$ & $\begin{array}{c}- \\
152 \\
6\end{array}$ & 2291 & $\begin{array}{c}322 \\
6\end{array}$ & $\begin{array}{c}- \\
527 \\
6\end{array}$ & $\begin{array}{c}195 \\
8\end{array}$ & $\begin{array}{c}3.13 \\
\text { E- } \\
04, \\
0.00\end{array}$ & $\begin{array}{l}15 \\
30\end{array}$ & 0.99 & 0.95 & $\begin{array}{l}0 . \\
89\end{array}$ \\
\hline $\begin{array}{c}\text { Coro } \\
\text { na } \\
\text { radia } \\
\text { ta }\end{array}$ & $\begin{array}{c}- \\
154 \\
5\end{array}$ & 2372 & $\begin{array}{c}312 \\
3\end{array}$ & $\begin{array}{c}- \\
514 \\
6\end{array}$ & $\begin{array}{c}205 \\
2\end{array}$ & $\begin{array}{c}3.13 \\
\text { E- } \\
04, \\
0.00\end{array}$ & $\begin{array}{l}16 \\
53\end{array}$ & 0.99 & 0.91 & $\begin{array}{c}0 . \\
80\end{array}$ \\
\hline
\end{tabular}

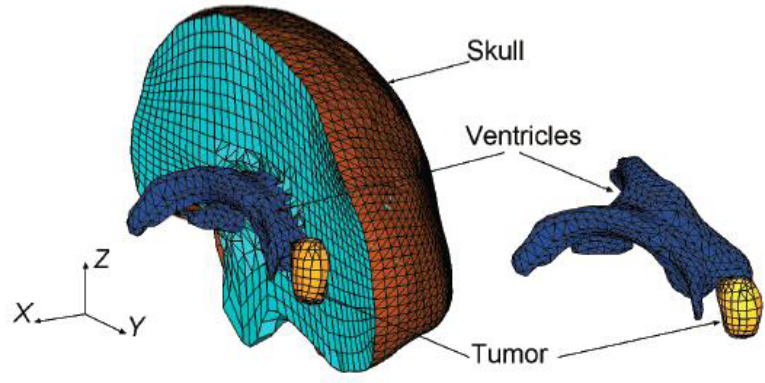

Figure 1. Patient-specific hexahedron-dominant brain mesh [28]

\section{Conclusion and Challenges}

From published experimental data, the mechanical response of brain tissue to external loading is very complex. The response is non-linear where brain tissue has a higher stiffness in compression than in tension. Three types of common brain tissue material models used in finite element analysis were discussed; namely the linear elastic, hyperelastic and viscoelastic. The linear elastic model is the simplest and computationally fast. However, this model is only accurate for strains up to $10 \%$. From these three models, the hyperelastic model, especially the Hyperfoam model represents accurately the tissue behavior up to strains of 50\% [12]. Quasi-linear viscoelastic models are good for strains up to $15 \%$. Hence, it can be concluded here that defining the elastic response of the brain tissue is best done with the hyperelastic material model. There is however some challenges that need to be address to make surgical simulation a reality. The challenge is for operation planning, the computational model must be patientspecific

\section{Acknowledgements}

This conference paper was made possible by NPRP grant \# (5 - 457 - 2 - 181) from the Qatar National Research Fund (a member of Qatar foundation). The statements made herein are solely the responsibility of the author(s).

\section{References}

[1] Guillaume Picinbono, Herve Delingette,Nicholas Ayache. Non-linear anisotropic elasticity for real-time surgery simulation. Graphical Models 65 (2003) 305-321

[2] Victoria Valinluck Lao, Scott R. Steele. The role of simulation in colon and rectal surgery training. Seminars in Colon and Rectal Surgery, In Press, Accepted Manuscript, Available online 14 April 2015

[3] Hsiu-Hsia Lin, Lun-Jou Lo. Three-dimensional computerassisted surgical simulation and intraoperative navigation in orthognathic surgery: A literature review. Journal of the Formosan Medical Association, 114 (4) 2015, 300307

[4] N. Abe, S. Kuroda, M. Furutani, E. Tanaka. Data-based prediction of soft tissue changes after orthognathic surgery: clinical assessment of new simulation software. International Journal of Oral and Maxillofacial Surgery, Volume 44 (1) 2015, 90-96

[5] Robert D. Acton. The Evolving Role of Simulation in Teaching Surgery in Undergraduate Medical Education. Surgical Clinics of North America, In Press, Corrected Proof, Available online 23 May 2015.

[6] Kwong Ming Tse, Long Bin Tan, Shu Jin Lee, Siak Piang Lim, Heow Pueh Lee. Investigation of the relationship between facial injuries and traumatic brain injuries using a realistic subject-specific finite element head model. Accident Analysis \& Prevention, 79, 2015, 13-32. 
[7] Jennifer A. DeWit, Duane S. Cronin. Cervical spine segment finite element model for traumatic injury prediction. Journal of the Mechanical Behavior of Biomedical Materials, 10, June 2012, 138-150.

[8] Lei Cheng, Blake Hannaford. Finite Element Analysis for evaluating liver tissue damage due to mechanical compression. Journal of Biomechanics, 48 (6) 2015, 948955.

[9] Skrinjar O Nabavi, A Duncan. Model driven brain shift compensation. Medical Image Analysis, 6(4), 2002. 361 373.

[10] Warfield SK, F. Talos, et. al. Real time registration of volumetric brain MRI by biomechanical simulation of deformation during image guided neurosurgery. Computing and Visualization in Science, 5 (1), 2001, 3 11.

[11] Ferrant M, Warrant SK, et al. Registration of 3D intraoperative MR images of the brain using a finite element biomechanical model. IEEE Transaction of medical Imaging, 20 (12), 2001, $1384-1397$.

[12] A. Mendizabal, I Aguinaga, E. Sanchez. Characterization and modelling of brain tissue for surgical simulation. Journal of the Mechanical behavior of Biomedical Materials 45, 2015, $1-10$.

[13] Sack Kaster, A . Samani. Measurement of the hyperelastic properties of ex vivo brain tissue slices. Journal of Biomechanics. 44 (6) 2011, 1158 - 1163

[14] C. Gao, K. Lister, J.P Desai. Constitutive modeling of liver tissue: experiment and theory. Annals of Biomedical Engineering 38 (2) 2010, 505-516.

[15] R.J. Lapeer, P.D Gasson, V. Karri. A hyperelastic finite element model of human skin for interactive real time surgical simulation. IEEE Transactions of Biomedical Engineering 58 (4), 1013 - 1022.

[16] J. Hug, R. Hutte, et. al. Virtual reality based simulation of endoscopic surgery. Presence: Teleoperat. Virtual Environment 9 (3), 2000, 310 - 333.

[17] Pals Martin, Natal Jorge, AJM Ferreira. A comparative study of sevral material models for predictions of Hyperelastic properties: application to silicon rubber and soft tissues. Strain 42 (3), 2006, 135-147.

[18] Richard Moran, Joshua H Smith, Jose J. Garcia. Fitted hyperelastic parameters for human brain tissue from reported tension, compression and shear tests. Journal of Biomechanics. 47, 2014, 3762-3766.

[19] A Yoshizawa, J. Okamoto, H Yamakawa, M.G. Fujie. Robot surgery based on the physical properties of the brain physical brain model for planning and navigation of a surgical robot. International conference on Robotics and Automation, April 2005. 904 - 911.

[20] Z. Liu, L. Bilston. On the viscoelastic character of a liver tissue. Experiment and modelling of the linear behavior. Biorheology 39 (6), 2000, 735 - 742.

[21] M. Sedef, E. Samur, C . Basdogan. Real time finite element simulation of linear viscoelastic tissue behavior based on experimental data. Computer Graphics and Applications, IEEE 26 (6) 2006, 28 - 38.

[22] L Yoo, V Gupta, et al. Viscoelastic properties of bovine orbital connective tissue and fat: constitutive models. Biomechanics Model Mechanobiology. 8 (1), 2011, 901 914.

[23] S. Misra, K. ramesh et al. Modeling of nonlinear elastic tissues for surgical simulation. Computational methods In Biomechanics . Biomedical engineering. 13 (6), 2010, 811-818.

[24] B Ahn, J. Kim. Efficient soft tissue characterization under large deformation in medical simulations. International Journal of Precision Engineering Manufacturing. 10 (4), 2009, $115-121$.
[25] D. Brands, G. Peters, P. Bovendeerd. Design and numerical implementation of the brain tissue during impact. Journal of Biomechanics. 37(1), 2004, 127 - 134.

[26] M Hrapko et al. The mechanical behavior of brain tissue: large strain response and constitutive modelling. Biorheology. 43(5), 2006, 623 - 636.

[27] L.E Bilston, Z. Liu, N. Phan Thien. Large strain behavior of brain tissue in shear. Some experimental data and differential constitutive model. Biorheology 38 (4) 2001, $335-345$.

[28] Karol Miller, Adam Wittek, Grand Joldes. Biomechanics of the brain for computer-integrated surgery. Acta of Bioengineering and Biomechanics. 12 (2), 2010, 25-37

[29] T J Horgan, M D Gilchrist.The creation of threedimensional finite element models for simulating head impact biomechanics. International Journal of Crash. 8(4), 2003, 353-366. 